\title{
The Indian Revolutionaries. The American Indian Movement in the 1960s and 1970s
}

The Red Power movement ${ }^{1}$ that arose in the 1960 s and continued to the late 1970s may be perceived as the second wave of modern pan-Indianism. ${ }^{2}$ It differed in character from the previous phase of the modern pan-Indian crusade ${ }^{3}$ in terms of massive support, since the movement, in addition to mobilizing numerous groups of urban Native Americans hailing from different tribal backgrounds, brought about the resurgence of Indian ethnic identity and Indian cultural renewal as well. ${ }^{4}$ Under its umbrella, there emerged many native organizations devoted to addressing the still unsolved "Indian question." The most important among them were the

\footnotetext{
1 The Red Power movement was part of a broader struggle against racial discrimination, the socalled Civil Rights Movement that began to crystalize in the early 1950s. Although mostly linked to the African-American fight for civil liberties, the Civil Rights Movement also encompassed other racial and ethnic minorities including Native Americans. See F. E. Hoxie, This Indian Country: American Indian Activists and the Place They Made, New York 2012, pp. 363-380.

2 It should be noted that there is no precise definition of pan-Indianism among scholars. Stephen Cornell, for instance, defines pan-Indianism in terms of cultural awakening, as some kind of new Indian consciousness manifested itself in "a set of symbols and activities, often derived from plains cultures." S. Cornell, The Return of the Native: American Indian Political Resurgence, New York 1988, p. 126. Hazel Hertzberg perceives pan-Indianism as a multidimensional strategy of Indian resistance against white oppression recognizing its military, political, and religious character. See H. W. Hertzberg, The Search for an American Identity: Modern Pan-Indian Movements, Syracuse 1971, p. 6. For D’Arcy McNickle, in turn, pan-Indianism associated with Indian nationalism, has both an ideological and political dimension. D. McNickle, Native American Tribalism: Indian Survivals and Renewals, New York 1993, pp. 170. One needs to indicate that premodern political pan-Indian movements are identified with such Indian leaders as Pontiac, Neolin and Tecumseh. See Encyclopedia of North American Indians, ed. F. E. Hoxie, New York 1996, p. 462.

3 The emergence of several pan-Indian organizations in the first three decades of the twentieth century marked the first stage of modern pan-Indianism. The most important among them were the Society of the American Indians and the Tepee Order of America. See C. Wilkinson, Blood Struggle: The Rise of Modern Indian Nations, New York 2005, p. 102.
}

4 J. Nagel, American Indian Ethnic Renewal: Red Power and the Resurgence of Identity and Culture, New York 1996, p. 6. 
National Indian Youth Council, the Survival of American Indians Association and the American Indian Movement. These supratribal ${ }^{5}$ groups, consisting largely of young Indians including students and veterans, were deeply interested in making changes in Indian policy. ${ }^{6}$ Although each of them had sometimes various sets of goals to achieve, they were all concerned with the issues of tribal sovereignty and self-determination - Indians' control over their own affairs. ${ }^{7}$

In this article, the author deals with the American Indian Movement (AIM), which turned out to be the most radical Indian organization during that time. AIM created its own ideology that combined traditional elements of Indian religions with the idea of "red nationalism". It also employed aggressive anti-government rhetoric and formulated a political program that addressed the question of sovereignty of the native nations.

The American Indian Movement was founded in 1968, in Minneapolis, by Dennis Banks, Clyde Bellecourt, George Mitchell, and Eddie Benton Banai, all Ojibwa Indians. The first two founders had criminal pasts behind them. They had both been sentenced to Stillwater State Prison, in Minnesota where, isolated with a lot of time to rethink their lives, they began to express interest in Indian history, familiarizing themselves especially with literature on the Ojibwa legacy. ${ }^{8}$ According to Vernon Bellecourt, Clyde Bellecourt's brother who later joined AIM, Clyde

\footnotetext{
5 The term "supratribal" is often interchangeably used with the term "pan-Indian". See, for inf stance, C. A. Oakley, Keeping the Circle: American Indian Identity in Eastern North Carolina, 1885-2004, Lincoln 2005, p. 75.

6 One should observe that federal policy toward Indians had many phases. In the nineteenth cenf tury, for example, the U.S. government, to deal with the so-called "Indian question," implemented three major strategies including separation, concentration, and Americanization (assimilation). See P. Weeks, Farewell, My Nation: The American Indian and the United States in the Nineteenth Century, Wheeling 2001, pp. 9-10. The next important step to regulate U.S.-Indian relations occurred in the 1930s when a special program under the Roosevelt administration, called the "Indian New Deal," went into effect. Its major law, the Indian Reorganization Act (IRA), was designed to abolish the allotment of native lands initiated by the Dawes Act in 1887, the key component of the policy of assimilation. Besides, IRA enabled "tribes to organize governments" and facilitated "them to incorporate - and partially consolidate - their trust lands." T. Holm, The Great Confusion in Indian Affairs: Native Americans and Whites in the Progressive Era, Austin 2005, p. 188; J. A. McDonnell, The Dispossession of the American Indian, 1887-1934, Bloomington 1991, pp. 1-3. After World War II, the federal government, in order to integrate American Indians more intensely with the dominant society, decided to return to the program of assimilation. Hailed as a "termination policy," this new strategy conducted during the 1940s-1960s, simply boiled down to "terminating the government's trust relationship over Indian lands and relocating the native residents to new homes in urban areas.” D. L. Fixico, Termination and Relocation: Federal Indian Policy, 1945-1960, Albuquerque 1986, p. ix.

7 S. L. Smith, Hippies, Indians, and the Fight for Red Power, Oxford 2012, pp. 21-24, 151.

8 D. Banks, R. Erdoes, Ojibwa Warrior: Dennis Banks and the Rise of the American Indian Movement, Norman 2004, pp. 60-63; J. L. Davis, Survival Schools: The American Indian Movement and Community Education in the Twin Cities, Minneapolis 2013, pp. 31-51.
} 
alongside his friend, Eddie Benton, "started an Indian awareness program in the prison and were instrumental in keeping our young Indian men out of jail once they got out". ${ }^{\prime}$

The movement drew its members mostly from young urban Native Americans. Many of them, in a search of a new identity, started to define themselves in terms of emerging pan-Indian consciousness, thus being susceptible to radical rhetoric. In this regard, Minneapolis seemed to be an ideal place for AIM to develop since this city possessed a significant Indian population. ${ }^{10}$ Being able to organize themselves, AIM's members instantly became engaged in local Indian community life. At first, its major initiative was the creation of a citizen patrol (the Indian Patrol) with its major function to observe police activity and protect intoxicated Indians from the brutality of law enforcement officers. ${ }^{11}$ Although it existed only for a few months, the Indian Patrol may be perceived as "a symbol of AIM's philosophy" that constituted "a symbolic representation of the AIM ideology of social change."12

As a local organization, the American Indian Movement from the beginning concentrated on supporting indigenous enclaves in Minneapolis and Minnesota. Its leaders advocated for better housing for Indians and were actively involved in the fight against unemployment soaring among the native people. ${ }^{13}$ By establishing the Legal Rights Center that provided professional services to Indians, AIM's activists were determined to wage a legitimate war against racial inequality. They also turned their attention to youth in terms of education. AIM instituted two schools for Indian children in Minnesota with Clyde Bellecourt and Eddie Banai as their major organizers. Lastly, the movement was involved in promoting Native American heritage by staging numerous cultural events including powwows, feasts, and other Indian gatherings. In general, the efforts of AIM's members were directed toward building a program to help to "organize to upgrade the condition in which the Indian lives, and to improve the stereotype of the Indian". ${ }^{14}$

9 V. Bellecourt, Birth of AIM, in Native American Testimony: A Chronicle of Indian and White Relations from Prophecy to Present 1492-1992, ed. P. Nabokov, New York 1991, p. 373.

10 D. L. Fixico, The Urban Indian Experience in America, Albuquerque 2000, p. 4.

11 It is worth mentioning that "it was a tactic similar to Black Panther campaigns to monitor police in Oakland, California and other cities." P. C. Smith, R. A. Warrior, Like A Hurricane: The Indian Movement from Alcatraz to Wounded Knee, New York 1996, p. 128.

12 F. G. Cohen, The Indian Patrol in Minneapolis: Social Control and Social Change in an Urban Context, "Law \& Society Review" 7 (1973), p. 783; N. Shoemaker, Urban Indians and Ethnic Choices: American Indian Organizations in Minneapolis 1920-1950, "The Western Historical Quarterly" 19 (1988), pp. 431-432.

13 The unemployment rate for Native Americans during the 1960s oscillated around 40\%. A. Forf tunate Eagle, Alcatraz! Alcatraz!: The Indian Occupation of 1969-1971, Berkeley 1992, p. 19.

14 AIM and Wounded Knee Documents, http://www.aics.org/WK/017.html (accessed 02.05.2016); J. L. Davis, op. cit., pp. 35, 96-97, 104, 160; Encyclopedia of the American Indian Movement, ed. B. E. Johansen, Santa Barbara 2013, p. xviii. 
In the early 1970s, however, the organization started to develop and modified its strategy. Its founders, in order to publicize the Indian struggle for equality, resolved to draw media attention and become more visible on the national scene, moving beyond the Indian urban communities. Moreover, they were convinced that using media served as a good opportunity to familiarize American public opinion with the problems faced by "red nations." Finally, AIM's members were eager to capture a new kind of audience, the reservation Indians. Altering the strategy also required a change in methods of operation and as early as the first half of the 1970s the movement began to grow into a militant organization. Because its leaders believed that only radical measures might bring desired results, they gradually started to implement various forms of political protest including demonstrations, takeovers, even resorting to militant occupation and gun violence. ${ }^{15}$

Of numerous actions conducted by AIM during the 1970s, there were several that attracted national attention. In 1970, for example, its activists occupied Mount Rushmore in South Dakota. In this manner, they expressed their opposition against the government's violation of the Treaty of Laramie that had granted the Lakota Indians ${ }^{16}$ the ownership of the Black Hills in $1868 .{ }^{17}$ During another operation on Thanksgiving Day 1970, AIM members arranged a "counter celebration" in Plymouth, Massachusetts. Protesting against the observance of this national holiday, they took control of Mayflower II, a replica of the first Pilgrim ship. In 1972, in turn, AIM's leaders alongside other Indian activists organized an automobile caravan to stage a demonstration in Washington. During this so-called "Trails of Broken Treaties," Indians prepared a 20-point document in which they proposed significant reforms in regard to federal Indian policy. ${ }^{18}$ They planned to present their grievances in front of Washington officials; however, when federal authorities refused to consider the Indians' demands, frustrated protesters occupied the building of the Bureau of Indian Affairs for a few days ${ }^{19}$.

\footnotetext{
15 Establishing chapters in major cities like Cleveland and Milwaukee attested to the fact that AIM began to grow in strength. W. Churchill, J. V. Wall, Agents of Repression: The FBI's Secret Wars against the Black Panther Party and the American Indian Movement, Boston 1990, pp. 119, 122-177.

16 The Lakotas or Tetons were the western division of the Sioux people. See, for example, R. M. Utley, The Lance and the Shield: The Life and Times of Sitting Bull, New York 1993, p. 4.

17 On the Fort Laramie Treaty of 1868 see J. Ostler, The Lakotas and the Black Hills: The Struggle for Sacred Ground, New York, 2010 pp. 58-69.

18 Some of its major points concerned the regulation of U.S.-Indian relations based on "restoration of the authority to make treaties with Indian communities." V. Deloria, Jr., Behind the Trail of Broken Treaties: An Indian Declaration of Independence, Austin 1985, p. viii.

19 Vernon Bellecourt, interview by A. N. Claypoole, December 15, 2000, http://bellecourtinn terview.blogspot.com/, (accessed 02.05.2016); Clyde Bellecourt, interview by Peter Gorman, Pee ter Gorman Archive, http://petergormanarchive.com/CLYDE_BELLECOURT.html, (accessed 02.05.2016).
} 
The most famous event in which the American Indian Movement became actively involved was the controversial siege of Wounded Knee. In 1973, some of the Sioux Indians from the Pine Ridge Reservation in South Dakota, the so-called "traditionalists", invited AIM to help them remove their corrupt tribal chairman, Richard Wilson. He was supported by the federal government and his rules were fervently opposed by the reservation Indians. ${ }^{20}$ Led by Russell Means ${ }^{21}$ and Dennis Banks, AIM's members quickly embraced the opportunity to publicize the Sioux struggle and thrust themselves into reservation politics against Wilson and his adherents. Their involvement resulted in the occupation of Wounded Knee, a small village on the Pine Ridge Reservation, where about three hundred Indians under the leadership of chief Big Foot had been slaughtered by the US army in $1890 .{ }^{22}$ When approximately two hundred AIM activists took control of the village, they proclaimed it to be a part of a new political entity, the Independent Oglala Nation. This instantly occasioned an armed occupation that lasted over two months during which the protesters confronted federal forces. Paradoxically, the siege of Wounded Knee, displaying the movement's strength, proved to be the peak of AIM's militant activity and marked the decline of its dynamics. ${ }^{23}$

The Wounded Knee incident rapidly provoked a national debate over the lot of Native Americans and their struggle for civil rights. The media images of modern Indian warriors fighting FBI officers and marshals kindled the imagination of the average American citizen who now had a chance to see a "real red man." Trying to capitalize on public attention, AIM's leaders were determined to initiate sharp negotiation with the federal government to address the most burning issues of Indian federal policy. Under the direction of Dennis Banks, they elaborated a "three-point program" that concerned the problem of Indian sovereignty and

20 One of AIM's members, Mary Brave Bird, also known as Mary Crow Dog, described Richard Wilson as "the corrupt and murderous half-blood tribal chairman at Pine Ridge." M. Brave Bird, R. Erdoes, Ohitika Woman, New York 1993, p. 27.

21 Although not the founder of AIM, Russell Means quickly became its most recognizable leader and coordinator. See P. Matthiessen, In the Spirit of Crazy Horse, New York 1983, p. 84.

22 Turning Hawk, Captain Sword, Spotted Horse, and American Horse (Sioux) - The Massacre at Wounded Knee, South Dakota, on December 29, 1890, in Great Documents in American Indian History, ed. W. Moquin, C. Van Doren, New York 1973, pp. 267-271. See also D. W. Grua, Surviving Wounded Knee: The Lakotas and the Politics of Memory, Oxford 2016, p. 1-3.

23 W. Kipp, Viet Cong at Wounded Knee: The Trail of A Blackfeet Activist, Lincoln 2004, pp. 115-131; P. C. Smith, R. A. Warrior, op. cit., pp. 205-17. Surveilled by the FBI and with is leaders, Dennis Banks and Russell Means, facing trials, the American Indian Movement lost its impetus after the Wounded Knee incident. Another blow came in 1976 when Leonard Peltier, one of AIM's leading activists, was arrested. The COINTELPRO Papers: Documents from the FBI's Secret Wars against Dissent in the United States, ed. W. Churchill, J.V. Wall, Boston 1990, pp. 246, 250, 260-1; J. W. Sayer, Ghost Dancing the Law: The Wound Knee Trials, Cambridge 2000, pp. 41-64.

24 “New York Times", 5.03.1973, p. 1; “Chicago Tribune", 2.03.1973, pp. 1, 8. 
self-determination ${ }^{25}$ including reexamination of Indian treaty rights, repealing of the Indian Reorganization Act of 1934 (IRA), and reforming the Bureau of Indian Affairs. ${ }^{26}$ This program was designed as

a strategy for nationally-coordinated attack on powerful financial and political interests, which have used the U.S. government to take advantage of Native Americans for more than a century. It will require strong commitment and wide support to win against these interests. Indian rights of sovereignty, self-government, and a decent means of living in accordance with traditions and believes will not come easily. ${ }^{27}$

The first point of AIM's political agenda touched upon the issue of Indian treaties. AIM's members stressed the fact that indigenous people were the only ethnic minority in the United States that had a legally established relationship with the federal government regulated through treaties. Those 371 agreements, as they argued, were considered lawful by all native tribes. They demanded that those contracts be reexamined by a special Treaty Commission and "all treaty rights should be enforced." ${ }^{28}$ The second point regarded the Indian Reorganization Act of 1934. AIM's leaders expressed concerns about this federal law which, in their view, had been created to deprive "Indians of their land; setting up white-controlled governments on many reservations, and establishing tribal constitutions which offer no real protection against sale and wholesale lease-out of tribal lands." ${ }^{29}$ Claiming that IRA constituted a major obstacle to Indian sovereignty, AIM activists advocated the repeal of this act and suggested that new tribal governments, devoid of federal influences, be installed on reservations . In their view, this process had already been initiated by Russell Means who, running for Lakota tribal chairman, tried to overcome his rival, a BIA puppet, Richard Wilson. ${ }^{30}$ Finally, the third point of

\footnotetext{
25 Charles Wilkinson defines the Indian sovereignty "in the narrow sense of the power of people to make governmental arrangements to protect and limit personal liberty by social control." C. Wilkinson, American Indians, Time, and the Law, New Haven 1987, pp. 54-55. Explaining the notion of self-determination, Vine Deloria, Jr. notices that the term defines nothing more than "opening up a certain amount of space between tribal governments and the federal government." V. Deloria, Jr., Intellectual Self-Determination and Sovereignty: Looking at the Windmills in Our Minds, "Wicazo Sa Review" 13 (1998), p. 26.

26 Dennis Banks, video interview, January 29, 1976, the Internet Archive, https://archive.org/details/cbpf_000036 (accessed 17.06.2016).

27 AIM and Wounded Knee Documents. AIM Three Point Program, http://www.aics.org/WK/032. html (accessed 22.06. 2016).

28 AIM and Wounded Knee Documents. AIM Three Point Program, http://www.aics.org/WK/030. html (accessed 19.06.2016).

29 AIM and Wounded Knee Documents. AIM Three Point Program, http://www.aics.org/WK/031. html (accessed 19.06.2016).

30 R. Means, M. J. Wolf, Where White Men Fear to Tread: The Autobiography of Russell Means, New York 1995, pp. 303-305.
} 
AIM's political plan focused on the Bureau of Indian Affairs. Instituted in 1824, the agency frequently directed its efforts against Indians. It was through the bureau that Washington maintained relations with all tribes, for the BIA served as some kind of an intermediary that distributed federal financial resources among the native people. ${ }^{31}$ Throughout its long history, this institution became permeated with corruption and a significant number of its agents gained ill fame for mismanagement of federal funds and selling Indian land. Movement leaders proposed that the Bureau of Indian Affairs be removed from the Department of the Interior and established as an independent body subject to the control of Native Americans. ${ }^{32}$

Examining AIM's political activism, one should observe, however, that this group could not operate without a certain ideological base to provide a reasonable justification for AIM's numerous strategies of political resistance. Although its founders did not formulate a sophisticated ideological system, they endeavored, to some extent, to build their movement on a concrete and solid foundation. After entering the national scene, they strove to forge a more cohesive vision for the future of their organization by adhering to native tradition and by promoting the idea of Indian nationalism.

To analyze AIM's ideology one needs to start with its religious aspect, for its members considered themselves to be a part of some kind of spiritual crusade. ${ }^{33}$ As the movement progressed, its leaders began to invoke a general native philosophy regarding the people's relationship with nature and the surrounding world. They claimed to recognize the weakness of the human race as being dependent on the earth's environment. Their Indianness, they argued, had enabled them to realize their own insignificance before Mother Earth and believe in a sacred bond between man and the environment. Embracing this universal Indian teaching that seemed deeply rooted in the cultural heritage of all native tribes inhabiting the United States, the movement's activists pointed out major differences between the traditional Indian world devoid of economic materialism and the civilization of the white man, which to them seemed nothing more than a contaminated and corrupted environment. ${ }^{34}$

\footnotetext{
31 W. E. Washburn, The American Indian and the United States: A Documentary History, New York 1973, vol. 1, p. 3.

32 Russell Means, video interview by C. Martinson, October 15, 1995, Claremont Colleges Digin tal Library, http://ccdl.libraries.claremont.edu/cdm/ref/collection/cmt/id/392 (accessed 20.06.2016); AIM and Wounded Knee Documents. AIM Three Point Program, http://www.aics.org/WK/032. html (accessed 20.06.2016).

33 L. W. Wittstock, E. J. Salinas, A Brief History of the American Indian Movement, American Indian Movement Grand Governing Council, http://www.aimovement.org/ggc/history.html (accessed 21.06.2016).

34 L. Crow Dog, R. Erdoes, Crow Dog: Four Generations of Sioux Medicine Men, New York 1995, pp. 161-163.
} 
The credo of the American Indian Movement was clearly defined by Russell Means during his trial in 1974. Means, in his opening statement to the jury, described the philosophy of the "red man" AIM had incorporated into its ideology. He explained that

we believe that all living things come from our sacred mother earth, all living things, the green things, the winged things of the air, the four leggeds, the things that crawl and swim, and of course, the two leggeds. It is our philosophy, it is our philosophy that because all living things come from one mother, our mother earth, then of course, we are all related and we have to - we have to treat one another with the same respect and reverence that we would our blood relatives. ${ }^{35}$

Though AIM's activists did not follow specific Indian religious systems, they adhered mostly to Lakota beliefs. This was not surprising since a significant part of them belonged to the Sioux and hence Sioux medicine men set the tone for the religious aspect of the movement. Those men, especially Wallace Black Elk and Leonard Crow Dog, presented themselves as AIM's holy guides who did not hesitate to refrain from criticizing white civilization, which, in their view, rested on the notion of technological progress and economic rivalry fueled, in turn, by people's greed. ${ }^{36}$ They taught that Indians living in the white man's realm ought to return to their cultural heritage and old traditional values. By turning to the Lakota sacred world, the American Indian Movement absorbed some basic elements from the Sioux religion including certain rituals and the concept of the supernatural embodied in Wakan Tanka, the Lakota Supreme Being, commonly known as the Great Spirit. ${ }^{37}$ He [the Great Spirit], as Wallace Black Elk attempted to explain to AIM members the complexity of Sioux beliefs:

talks to the fire, he talks to the trees and all green vegetations. And he talks to the stones and all minerals, and the water and the creatures - the creeping things, the crawling things, four-legged creatures and flying creatures (...) And its sacred altar is this Western Hemisphere. This land is sacred, it is an altar, and we know that we have spirit here at all times, and we have been talking to him. ${ }^{38}$

35 The Opening Statements of Russell Means and Dennis Banks, U.S. Vs. Russell Means and U.S. Vs. Dennis Banks, Wounded Knee Legal Defense/Offense Committee, Saint Paul 1974, n. pag.; G. Vizenor, Dennis of Wounded Knee, "American Indian Quarterly" 7 (1983), p. 52.

36 A. A. Znamenski, The Beauty of the Primitive: Shamanism and Western Imagination, Oxford 2007, p. 296.

37 Anthropologist Raymond DeMallie argues that for the Sioux Indians "Wakan Tanka was the sum of all that was considered mysterious, powerful, or sacred - equivalent to the basic meaning of the English word 'holy."' Sioux Indian Religion: Tradition and Innovation, ed. R. J. DeMallie, D. R. Parks, Norman 1987, p. 28.

38 Akwesasne Notes, Voices from Wounded Knee, 1973, Rooseveltown 1974, p. 104. 
Yet, it was Sioux ritual that occupied an essential place in AIM's ideology. The major Lakota ceremonies including the Sun Dance and the Ghost Dance were restored by Leonard Crow Dog, who played a crucial role in the Indian cultural renewal in the Red Power era. For AIM's activists the restoration of the Ghost Dance was of special importance, especially during the siege of Wounded Knee when they claimed to be in great need of spiritual support. The Ghost Dance had been introduced to the Lakotas in 1890 by the Paiute prophet, Wovoka ${ }^{39}$, who maintained that participation in this ritual enabled the living to communicate with the dead. Through taking part in the ceremony, AIM's members asserted that they were able to resume the sacred bond with those Lakota Indians who had died during the massacre of Wounded Knee in $1890 .^{40}$

The ideological foundation of the American Indian Movement not only contained a religious aspect. Trying to gain mass support among all native nations, AIM's leaders resorted to resurrecting nationalistic (pan-Indian) sentiment in Indians across the country. They were convinced that the notion of pan-Indianism would strongly appeal to Indian mentality regardless of their tribal affiliation. ${ }^{41}$ Propagating the concept of native unity, they strove to restore the vision of Tecumseh, the leader of the Shawnee who had formed a large Indian confederacy that fought the United States during the years 1811-1813. To stress the significance of supratribal unification, AIM's founders cited the words of the Shawnee chief, who indicated that:

each year, our White intruders become more exacting, oppressive, demanding, and overbearing. Wants and oppression are our lot. Are we not being stripped day by day of the little that remains of our ancient liberty? Unless each tribe unanimously combines to give a check to the avarice and oppressions of the white, we will become conquered and disunited and we will be driven from our Native Lands and scattered like autumn leaves before the wind. ${ }^{42}$

\footnotetext{
39 A Northern Paiute, Wovoka was also known under the name Jack Wilson. He considered himm self a spiritual practitioner who preached that Indians, by performing a special ritual named Ghost Dance, would bring their all dead relatives to life and make the whites disappear. In the end, the old native way of life would be restored. See I Have Spoken: American History Through the Voices of the Indians, ed. V. I. Armstrong, Chicago 1971, pp. 128-129; R. M. Underhill, Red Man's America: A History of Indians in the United States, Chicago 1971, p. 266.

40 M. Crow Dog, R. Erdoes, Lakota Woman, New York 1990, pp. 144-145; G. G. Valaskakis, Indian Country: Essays on Contemporary Native Culture, Waterloo 2005, p. 172.

${ }_{41}$ R. Means, On the Siege of Wounded Knee, in Competing Voices from Native America: Fighting Words, ed. J. Porter, D. I. Ball, Westport 2008, p. 238.

42 Akwesasne Notes, B. I. A., I'm Not Your Indian Anymore, Rooseveltown 1974, n. pag.; R. A. Bonney, The Role of AIM Leaders in Indian Nationalism, "American Indian Quarterly" 3 (1997), pp. 218-219.
} 
It should be emphasized that AIM was created in the era of the Civil Rights Movement thereby its major members comprehended that belonging to a certain ethnic out-group put restrictions on their ability to voice their demands publicly. ${ }^{43}$ Thus in order to sound realistic and persuasive, they had to utilize explicit and even aggressive rhetoric. They did so by attempting to convince their listeners that AIM was waging a war against a particular enemy or enemies. Yet, their rhetoric was not pointed toward strictly specific individuals but rather aimed at collectively defined opponents. Not ashamed of their criminal backgrounds, AIM's activists indicated that

when we started becoming acquainted with AIM and the teachings, a lot of us had come out of prisons, institutions, the orphanages, the bars, and years of being oppressed. We brought that hate with us into the Movement. That's why we were so quick to pick up the guns and the arms to fight our enemy. Our enemy at that time was the government forces because they were the most visible ones who were causing pain upon our people and our way of life. We let that determine our actions at the time. ${ }^{44}$

AIM's members regarded themselves as warriors who followed the tradition of their ancestors in a ceaseless struggle against the white man's oppressive political system. ${ }^{45}$ Their adversary, however, was not that different from the one their forefathers had fought during the eighteen and nineteenth centuries. It was still the federal government, but this time armed with new, more powerful weapons of persecution. Some radicals like Russell Means, who may be perceived as the movement's major spokesman, had a tendency to multiply AIM's opponents adding American multinational corporations and even the entire American nation to the list of AIM's enemies. In his fiery speech to the United Nations, in 1977, Means compared the United States to a big monster that was devouring its Indian inhabitants. Then, appealing to the consciousness of global society, he summoned "the international community this first time for support and assistance to stop not only this rape of our mother earth, but also to stop the genocide of a whole people". ${ }^{46}$

This kind of language, the rhetoric of victimization employed to address especially the problem of Indian genocide, placed in the context of American

43 J. Sanchez, M. E. Stuckey, The Rhetoric of American Indian Activism in the 1960s and 1970s, "Communication Quarterly" 48 (2000), p. 120.

44 Dino Butler, interview by E.K. Caldwell, 1995, http://www.dickshovel.com/dino.html, (accessed 29.06.2016).

45 L. Peltier, Prison Writings: My Life is My Sundance, New York 1999, pp. 94-95.

46 R. Means, We Are People Who Live in the Belly of the Monster, speech delivered in Geneva, September 20, 1977 in Great Speeches by Native Americans, ed. B. Blaisdell, Mineola 2000, p. 214; Dennis Banks, video interview by J. Smith, November 15, 2009, Grand Rapids, http://griid. org/2009/11/15/interview-with-dennis-banks (accessed 29.06. 2016). 
colonialism and imperialism, was also very often used by AIM's activists. ${ }^{47}$ They discerned three types of ethnic "holocaust": physical, cultural, and spiritual. The first one, that almost entirely decimated the Indian population, seemed to have ended in the second half of the nineteenth century. But according to Dennis Banks, physical genocide was still taking place since Indians "are still a conquered people" and their "children are taken away from us, stolen, sent to boarding schools hundreds of miles away" ${ }^{48}$ Cultural annihilation that, on the other hand, not only aimed at the destruction of Indian heritage but also at perpetuating negative Indian stereotypes, manifested itself, as Clyde Bellecourt stressed, in " the anti-Indian attitude, the anti-Indian legislation, and the John Wayne mentality that exists among the media today". ${ }^{49}$ Moreover, some of AIM's members accentuated that Native Americans were not merely subjected to physical and cultural extermination but also had become the victims of a spiritual genocide at the hands of the white men who

have limited our ability to see the necessity for our survival because they want us to believe that genocide just means physical extinction. But we must consider the spiritual genocide that's committed against us. The spiritual genocide that the white people have been victimized for thousands of years. The spiritual genocide that told them not to respect the earth. Not to respect the life that is earth. But to pay all of their tribute through the churches to god in heaven and that heaven would take care of it in the afterlife. ${ }^{50}$

One should point out, however, that AIM's most aggressive verbal attacks were directed against the entire civilization created by the dominant white society. ${ }^{51}$ In this regard, the movement's enemy assumed the form of an inhuman adversary that could be easily assaulted without having an opportunity to defend itself. By picking this kind of target, AIM's rhetoric began to bear a striking resemblance to anarchist propaganda. Although the movement's activists were far from identifying

\footnotetext{
47 Such themes as neocolonialism, colonialism, capitalism, industrialism and genocide were frequt ently utilized in the rhetoric of the American Indian activists to describe white attitudes toward indigenous people. Robert Robideau, interview by J. Allen, “Socialist Worker," July 28, 2009, https:// socialistworker.org/2009/07/28/fbi-war-on-indian-radicals, (accessed 22.06.2016); W. LaDuke, The Winona LaDuke Reader: A Collection of Essential Writings, Stillwater 2002, pp. 82-84.

48 K. S. Stern, Loud Hawk: The United States versus the American Indian Movement, Norman 1994, p. 23.

49 C. Bellecourt, untitled speech delivered in Washington, D.C., July 15, 1978 in Voices of Multicultural America, ed. D. G. Straub, Detroit 1996, p. 31.

50 Stickman: John Trudell, Poems, Lyrics, Talks, a Conversation, ed. P. Igliori, New York 1994, n. pag. On white attitude toward AIM see M. Meister, A. Burnette, Rhetorical Exclusion in the Trial of Leonard Peltier, "American Indian Quarterly," 28 (2004), p. 734-5.

51 The FBI files on Russell Means, SA Byron H. Dunbar, American Indian Movement, 11/28/73, the Internet Archive, https://ia601501.us.archive.org/5/items/RussellMeans/1202154-0-105a-bt1140-Section1.pdf (accessed 02.07.2016).
} 
themselves with any kind of political philosophy, it did not mean they were not susceptible to radical political thought. "I come from an anarchist, matriarchal culture where freedom of the individual is paramount," claimed Russell Means without concealing his revolutionary sympathies. ${ }^{52} \mathrm{He}$, along with another AIM extremist, John Trudell ${ }^{53}$, were the ones who most fiercely condemned the economic and technological achievements of the dominant culture. In his criticism of white civilization, Means particularly attacked Europe's intellectual heritage, holding "the European materialist tradition" responsible for all the disasters that had afflicted the Indian people. According to him, such ideologies as capitalism, Christianity, even Marxism, fostered the idea of material progress among Europeans. Civilizational development, in turn, contributed to the destruction of Indian tribal life and was affecting young generations of native people, who, raised and educated in white man's society, could easily acquire its contaminated mindset. Blaming Europe's cultural legacy for all the Indians' misfortunes, Means accused European philosophers of laying the foundation for the emergence of Europe's predatory mentality. He lamented that

Hegel and Marx were heirs to the thinking of Newton, Descartes, Locke and Smith (...) Marx put Hegel's philosophy in terms of "materialism," which is to say that Marx despiritualized Hegel's work altogether. Again, this is in Marx' own terms. And this is now seen as the future revolutionary potential of Europe. Europeans may see this as revolutionary, but American Indians see it simply as still more of that same old European conflict between being and gaining. The intellectual roots of a new Marxist form of European imperialism lie in Marx' and his followers' - links to the tradition of Newton, Hegel and others. ${ }^{54}$

It should be noted that AIM's leaders did not solely condemn the corrupted world of the "despotic race". Sometimes they proposed solutions on how to resist white influences. For instance, in Trudell's view, Native Americans had to devise new tactics to learn how to be vigilant and patient in dealing with their enemy. He believed that, in order to unite themselves in a common struggle against white civilization, Indians

must go beyond the arrogance of human rights; we must go beyond the ignorance of civil rights; and we must step into the reality of natural rights because

\footnotetext{
52 R. A. Lake, C. H. Palczewski, Russell Means, in American Voices: An Encyclopedia of Contemporary Orators, ed. B. K. Duffy, R. W. Leeman, Westport 2005, p. 320.

53 Trudell had already been an experienced activist. Between 1969 and 1971, he participated in the famous occupation of Alcatraz during which 89 Indians decided to claim the island under the Fort Laramie Treaty of 1868. See P. C. Smith, R. A. Warrior, op. cit., pp. 60-83.

54 R. Means, For America to Live, Europe Must Die, speech delivered in July, 1980 at Black Hills International Survival Gathering, South Dakota, https://archive.org/stream/ForAmericaToLiveEuropeMustDie/ (accessed 02.07.2016); R. Weyler, Blood of the Land: The Government and Corporate War against the American Indian Movement, New York 1982, pp. 230-231.
} 
all of the natural world has a right to existence and we are only a small part of it. There can be no trade-off. We are the people. We have the potential for power. It takes more than good intentions, it takes commitment. It takes that at some point in our lives we're going to have to decide that we have a way of life that we follow and we're going to have to live to that way of life, even when our enemies totally surround us (...)That is the only solution there for us. ${ }^{55}$

Unquestionably, the American Indian Movement was one of the most visible ethnic organizations during the Civil Rights era. It was also the most radical political group among Native Americans in the 1960s and 70s distinguishing itself by its militant character. Its ideology and rhetoric, targeting a sociopolitical order established by the dominant culture, were instrumental in educating their American audience about the injustices "red people" have suffered from their white oppressors. Moreover, they justified the movement's political program, sanctioned its controversial actions and served as a signpost to define AIM's members' identity and their relationship with the surrounding reality. ${ }^{56}$

Although the American Indian Movement failed to accomplish its radical objectives, its participation in the broader Civil Rights Movement brought desired changes in federal Indian policy in the 1970s. ${ }^{57}$ AIM's political activism also contributed to the reorientation of the national debate on the image of Native Americans in the dominant society. The American people saw that Indians were not only the silent remnants of a distant epoch but real individuals who were determined to have their own voice to stand up for their rights. AIM's activism, stressing pride in their indigenous heritage, had also a stimulating impact on Indian communities in encouraging them to be more engaged not only in national politics but also in the preservation of tribal culture. On the other hand, however, AIM's postulates seemed too extreme and its actions, perceived sometimes as a theatrical grotesque,

\footnotetext{
55 Stickman, op., cit., n. pag.

56 Weakened in the 1970s, AIM never regained its former strength. During the 1990s it split into two separate organizations: the AIM Grand Governing Council under the leadership of Vernon Bellecourt and the AIM-International Confederation of Autonomous Chapters with Russell Means as its director. See D. L. Fixico, Indian Resilience and Rebuilding: Indigenous Nations in the Modern American West, Tucson 2013, p. 149.

57 Although the first signs of change in federal Indian policy appeared with the passing of the controversial Indian Civil Rights Act of 1968, a new era of U.S.-Indian relations was initiated in the 1970s. Its cornerstone turned out to be the Indian Self-Determination and Education Assistance Act passed by Congress in 1975. In general, this act gave native tribes much more control over their own affairs since it facilitated "the full participation of Indian tribes in programs and services conducted by the Federal Government for Indians." Indian Self-Determination and Education Assistance Act Implementation, Hearings before the United States Senate Select Committee on Indian Affairs, Ninety-Fifth Congress, First Session on Implementation of Public Law 93-638 - The Indian Self-Determination and Education Assistance Act, June 7 and 24, 1977, p. 3; F. P. Prucha, The Great Father: The United States Government and the American Indians, Lincoln 1984, p. 379; W. Mankiller, M. Wallis, Mankiller: A Chief and Her People, New York 1993, pp. 188-189.
} 
too radical. Moreover, AIM's leaders were considered by some critics "tribal simulations with dubious constituencies" whose "stoical poses, tragic and lonesome, were closer to photographic and video images familiar to a consumer culture." 58

\section{The Indian Revolutionaries. The American Indian Movement in the 1960s and 1970s}

\section{Summary}

The ideas of supra-tribal unity and Indian nationalism arising among Native Americans in the 20th century initiated the phenomenon defined by the American historians as modern Pan-Indianism. Its first phase occurred at the beginning of the 20th century whereas the second one, more apparent, is connected with the so called "Red Power" movement and dates back to the 1960s and 1970s. During this stormy period for the USA, when ethnic minorities started to openly manifest their postulates for equality, American Indians took their voice thereon too. Due to its extremism, American Indian Movement was the top one among many Indian groups that emerged at that time. The organization founded in 1968 by Dennis Banks and Russell Means quickly attracted American public attention due to their radical actions. The Movement was the most active in the 1960s and 1970s. At that time, relying on aggressive anti-government rhetoric, AIM created a peculiar ideology invoking Indian tribal spirituality, and proposed their own political program focusing on the issue of obtaining full sovereignty by Indian peoples and reforming federal policy towards Native Americans.

Key words: The United States of America, North American Indians, Pan-Indianism, "Red Power" Movement, American Indian Movement

\section{Indiańscy rewolucjoniści. Ruch Indian Amerykańskich w latach sześćdziesiątych i siedemdziesiątych XX wieku}

\section{Streszczenie}

W XX w. budzące się wśród tubylczych Amerykanów idee jedności ponadplemiennej i nacjonalizmu indiańskiego dały początek zjawisku określanemu przez historyków amerykańskich jako nowoczesny panindianizm. Jego pierwsza faza przypada na początek XX stulecia natomiast druga, bardziej wyrazista, związana z tzw. ruchem „Red Power” jest datowana na lata sześćdziesiąte i siedemdziesiąte

58 Shadow Distance: A Gerald Vizenor Reader, ed. A. R. Lee, Hanover 1994, p. 232. 
XX wieku. W tym burzliwym dla Ameryki okresie, gdy mniejszości etniczne zaczęły głośno manifestować swoje postulaty równouprawnienia, również Indianie zapisali swą kartę. Spośród wielu grup indiańskich, które wówczas powstały, na czoło wybił się swoim ekstremizmem Ruch Indian Amerykańskich (American Indian Movement). Założona w 1968 r. organizacja ta, pod przywództwem Dennisa Banksa i Russella Meansa, szybko przykuła uwagę amerykańskiej opinii publicznej radykalnymi akcjami. Apogeum działalności Ruchu przypadło na lata sześćdziesiąte i siedemdziesiąte XX stulecia. Wówczas AIM, posiłkując się agresywną retoryką antyrządową, stworzył swoistą ideologię odwołującą się do indiańskiej duchowości plemiennej oraz wysunął własny program polityczny odnoszący się do kwestii uzyskania pełnej suwerenności przez narody indiańskie i zreformowania federalnej polityki wobec tubylczych Amerykanów.

Słowa kluczowe: Stany Zjednoczone, Indianie Ameryki Północnej, Panindianizm, Ruch „Red Power”, Ruch Indian Amerykańskich

\section{Bibliography}

\section{Published Sources}

Akwesasne Notes, B. I. A., I'm Not Your Indian Anymore, Rooseveltown 1974.

Akwesasne Notes, Voices from Wounded Knee, 1973, Rooseveltown 1974.

Banks D., Erdoes R., Ojibwa Warrior: Dennis Banks and the Rise of the American Indian Movement, Norman 2004.

Bellecourt C., untitled speech delivered in Washington, D.C., July 15, 1978 in Voices of Multicultural America, ed. D. G. Straub, Detroit 1996.

Bellecourt V., Birth of AIM, in Native American Testimony: A Chronicle of Indian and White Relations from Prophecy to Present 1492-1992, ed. P. Nabokov, New York 1991.

Brave Bird M., Erdoes R., Ohitika Woman, New York 1993.

"Chicago Tribune", 2.03.1973.

The COINTELPRO Papers: Documents from the FBI's Secret Wars against Dissent in the United States, ed., W. Churchill, J.V. Wall, Boston 1990.

Crow Dog L., Erdoes R., Crow Dog: Four Generations of Sioux Medicine Men, New York 1995.

Crow Dog M., Erdoes R., Lakota Woman, New York 1990.

Fortunate Eagle A., Alcatraz! Alcatraz!: The Indian Occupation of 1969-1971, Berkeley 1992.

I Have Spoken: American History Through the Voices of the Indians, ed. V. I. Armstrong, Chicago 1971. 
Indian Self-Determination and Education Assistance Act Implementation, Hearings before the United States Senate Select Committee on Indian Affairs, Ninety-Fifth Congress, First Session on Implementation of Public Law 93-638 - The Indian Self-Determination and Education Assistance Act, June 7 and 24, 1977.

Kipp W., Viet Cong at Wounded Knee: The Trail of A Blackfeet Activist, Lincoln 2004.

LaDuke W., The Winona LaDuke Reader: A Collection of Essential Writings, Stillwater 2002.

Mankiller W., Wallis M., Mankiller: A Chief and Her People, New York 1993.

Means R., On the Siege of Wounded Knee, in Competing Voices from Native America: Fighting Words, ed. J. Porter, D. I. Ball, Westport 2008.

Means R., We Are People Who Live in the Belly of the Monster, speech delivered in Geneva, September 20, 1977 in Great Speeches by Native Americans, ed. B. Blaisdell, Mineola 2000.

Means R., Wolf M. J., Where White Men Fear to Tread: The Autobiography of Russell Means, New York 1995.

"New York Times", 5.03.1973.

The Opening Statements of Russell Means and Dennis Banks, U.S. Vs. Russell Means and U.S. Vs. Dennis Banks, Wounded Knee Legal Defense/Offense Committee, Saint Paul 1974.

Peltier L., Prison Writings: My Life is My Sundance, New York 1999.

Shadow Distance: A Gerald Vizenor Reader, ed. A. R. Lee, Hanover 1994.

Stern K. S., Loud Hawk. The United States versus the American Indian Movement, Norman 1994.

Stickman: John Trudell, Poems, Lyrics, Talks, a Conversation, ed. P. Igliori, New York 1994.

Turning Hawk, Captain Sword, Spotted Horse, and American Horse (Sioux) - The Massacre at Wounded Knee, South Dakota, on December 29, 1890, in Great Documents in American Indian History, ed. W. Moquin, C. Van Doren, New York 1973.

Washburn W. E., The American Indian and the United States: A Documentary History, New York 1973, vol. 1.

\section{Internet Sources (Interviews)}

Dennis Banks, video interview, January 29, 1976, the Internet Archive, https://archive.org/ details/cbpf_000036

Dennis Banks, video interview by J. Smith, November 15, 2009, Grand Rapids, http:/griid. org/2009/11/15/interview-with-dennis-banks

Clyde Bellecourt, interview by P. Gorman, Peter Gorman Archive, http://petergormanarchive.com/CLYDE_BELLECOURT.html 
Vernon Bellecourt, interview by A. N. Claypoole, December 15, 2000, http://bellecourtinterview.blogspot.com/

Dino Butler, interview by E.K. Caldwell, 1995, http://www.dickshovel.com/dino.html

Russell Means, video interview by C. Martinson, October 15, 1995, Claremont Colleges Digital Library, http://ccdl.libraries.claremont.edu/cdm/ref/collection/cmt/id/392

Robert Robideau, interview by J. Allen, “Socialist Worker,” July 28, 2009, https://socialistworker.org/2009/07/28/fbi-war-on-indian-radicals

\section{Other Internet Sources}

AIM and Wounded Knee Documents, http://www.aics.org/WK/

The FBI files on Russell Means, SA Byron H. Dunbar, American Indian Movement, 11/28/73, the Internet Archive, https://ia601501.us.archive.org/5/items/RussellMeans/1202154-0-105a-bt-1140-Section1.pdf

R. Means, For America to Live, Europe Must Die, speech delivered in July, 1980 at Black Hills International Survival Gathering, South Dakota, https://archive.org/stream/ ForAmericaToLiveEuropeMustDie/

L. W. Wittstock, E. J. Salinas, A Brief History of the American Indian Movement, American Indian Movement Grand Governing Council, http://www.aimovement.org/ggc/ history.html

\section{Secondary Sources}

Bonney A. R., The Role of AIM Leaders in Indian Nationalism, “American Indian Quarterly" 3 (1997).

Churchill W., Wall J. V., Agents of Repression: The FBI's Secret Wars against the Black Panther Party and the American Indian Movement, Boston 1990.

Cohen F. G., The Indian Patrol in Minneapolis: Social Control and Social Change in an Urban Context, "Law \& Society Review" 7 (1973).

Cornell S., The Return of the Native: American Indian Political Resurgence, New York 1988.

Davis J. L., Survival Schools: The American Indian Movement and Community Education in the Twin Cities, Minneapolis 2013.

Deloria V. Jr., Behind the Trail of Broken Treaties: An Indian Declaration of Independence, Austin 1985.

Deloria V. Jr., Intellectual Self-Determination and Sovereignty: Looking at the Windmills in Our Minds, "Wicazo Sa Review" 13 (1998).

Encyclopedia of the American Indian Movement, ed. B. E. Johansen, Santa Barbara 2013.

Encyclopedia of North American Indians, ed. F. E. Hoxie, New York 1996.

Fixico D. L., Indian Resilience and Rebuilding: Indigenous Nations in the Modern American West, Tucson 2013. 
Fixico D. L., Termination and Relocation: Federal Indian Policy, 1945-1960, Albuquerque 1986.

Fixico D. L., The Urban Indian Experience in America, Albuquerque 2000.

Grua D. W., Surviving Wounded Knee: The Lakotas and the Politics of Memory, Oxford 2016.

Hertzberg H. W., The Search for an American Identity: Modern Pan-Indian Movements, Syracuse 1971.

Holm T., The Great Confusion in Indian Affairs: Native Americans and Whites in the Progressive Era, Austin 2005.

Hoxie F. E., This Indian Country: American Indian Activists and the Place They Made, New York 2012.

Lake R. A., Palczewski C. H., Russell Means, in American Voices: An Encyclopedia of Contemporary Orators, ed. B. K. Duffy, R. W. Leeman, Westport 2005.

Matthiessen P., In the Spirit of Crazy Horse, New York 1983.

McDonnell J. A., The Dispossession of the American Indian, 1887-1934, Bloomington 1991.

McNickle D., Native American Tribalism: Indian Survivals and Renewals, New York 1993.

Meister M., Burnette A., Rhetorical Exclusion in the Trial of Leonard Peltier, "American Indian Quarterly", 28 (2004).

Nagel J., American Indian Ethnic Renewal: Red Power and the Resurgence of Identity and Culture, New York 1996.

Oakley C. A., Keeping the Circle: American Indian Identity in Eastern North Carolina, 1885-2004, Lincoln 2005.

Ostler J., The Lakotas and the Black Hills: The Struggle for Sacred Ground, New York 2010.

Sanchez J., Stuckey M. E., The Rhetoric of American Indian Activism in the 1960s and 1970s, "Communication Quarterly" 48 (2000).

Sayer J. W., Ghost Dancing the Law: The Wound Knee Trials, Cambridge 2000.

Shoemaker N., Urban Indians and Ethnic Choices: American Indian Organizations in Minneapolis 1920-1950, “The Western Historical Quarterly” 19 (1988).

Sioux Indian Religion: Tradition and Innovation, ed. R. J. DeMallie, D. R. Parks, Norman 1987.

Smith P. C., Warrior R. A., Like A Hurricane: The Indian Movement from Alcatraz to Wounded Knee, New York 1996.

Smith S. L., Hippies, Indians, and the Fight for Red Power, Oxford 2012.

Underhill R. M., Red Man's America: A History of Indians in the United States, Chicago 1971.

Utley R. M., The Lance and the Shield: The Life and Times of Sitting Bull, New York 1993. 
Valaskakis G. G., Indian Country: Essays on Contemporary Native Culture, Waterloo 2005.

Vizenor G., Dennis of Wounded Knee, “American Indian Quarterly” 7 (1983).

Weeks P., Farewell, My Nation: The American Indian and the United States in the Nineteenth Century, Wheeling 2001.

Weyler R., Blood of the Land: The Government and Corporate War against the American Indian Movement, New York 1982.

Wilkinson C., American Indians, Time, and the Law, New Haven 1987.

Wilkinson C., Blood Struggle: The Rise of Modern Indian Nations, New York 2005.

Znamenski A. A., The Beauty of the Primitive: Shamanism and Western Imagination, Oxford 2007. 